January 2015

\title{
Educational infrastructure and resources for sustainable access to schooling and outcomes: the case of early literacy development in southern Tanzania
}

Marriote Ngwaru

Aga Khan University, marriote.ngwaru@aku.edu

Mary Oluga

Aga Khan University, mary.oluga@aku.edu

Follow this and additional works at: https://ecommons.aku.edu/eastafrica_ied

Part of the Educational Assessment, Evaluation, and Research Commons, and the Elementary and Middle and Secondary Education Administration Commons

\section{Recommended Citation}

Ngwaru, M., Oluga, M. (2015). Educational infrastructure and resources for sustainable access to schooling and outcomes: the case of early literacy development in southern Tanzania. Africa Education Review, 12(1), 88-108.

Available at: https://ecommons.aku.edu/eastafrica_ied/66 


\title{
EDUCATIONAL INFRASTRUCTURE AND RESOURCES FOR SUSTAINABLE ACCESS TO SCHOOLING AND OUTCOMES: THE CASE OF EARLY LITERACY DEVELOPMENT IN SOUTHERN TANZANIA
}

\author{
Jacob Marriote Ngwaru \& Mary Oluga
}

To cite this article: Jacob Marriote Ngwaru \& Mary Oluga (2015) EDUCATIONAL INFRASTRUCTURE AND RESOURCES FOR SUSTAINABLE ACCESS TO SCHOOLING AND OUTCOMES: THE CASE OF EARLY LITERACY DEVELOPMENT IN SOUTHERN TANZANIA, Africa Education Review, 12:1, 88-108, DOI: 10.1080/18146627.2015.1036570

To link to this article: http://dx.doi.org/10.1080/18146627.2015.1036570

Published online: 27 Jul 2015.

Submit your article to this journal $\widetilde{ }$

山 Article views: 258

View related articles

View Crossmark data $\asymp$ 


\section{EDUCATIONAL INFRASTRUCTURE AND RESOURCES FOR SUSTAINABLE ACCESS TO SCHOOLING AND OUTCOMES: THE CASE OF EARLY LITERACY DEVELOPMENT IN SOUTHERN TANZANIA}

\section{Jacob Marriote Ngwaru}

marriote.ngwaru@aku.edu

\section{Mary Oluga}

The Aga Khan University

Institution for Educational Development, East Africa

Dar-Es-Salaam, Tanzania

mary.oluga@aku.edu

\section{ABSTRACT}

Following on the 1990 and 2000 World Conferences on Education for All, African governments increased their focus on access to schooling (but not necessarily on outcomes) by providing more facilities for increased enrolments. The learning outcomes that had been neglected led to a call to focus on more sustainable access - re-examining the quality of some of those facilities against the anticipated quality of educational outcomes. Studies in Southern and Eastern Africa, including the one under discussion here, indicate that the achievement of the Millennium Development Goals (MDGs) will not rely only on school-based factors but also on the careful analysis of wider socioeconomic and cultural factors. This paper, through the results of the case study component of the Early Literacy Development project in the Lindi Rural District of Southern Tanzania, discusses why literacy development has lagged behind in SubSaharan Africa. The focus of the study and of this paper is on the relationship between literacy practices, literacy events and early literacy development at

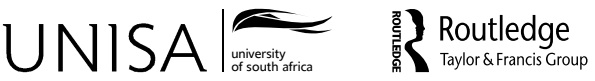


home and school in low-resourced communities. The extent to which school infrastructure and ecology including buildings, teaching learning materials and teacher characteristics reinforced literacy practices and events at home and school is also highlighted as being of special interest.

The study was sponsored by the Canadian Department of Foreign Affairs and Trade Development (formerly CIDA) - Strengthening Education Systems in East Africa (SES-EA).

Keywords: Millennium Development Goals, literacy development, literacy practices and events, classroom factors, home and school infrastructure and ecology, sustainable access, educational outcomes

\section{BACKGROUND}

\subsection{Achieving educational Millennium Development Goals in Sub-Saharan Africa}

The eight United Nations Millennium Development Goals (MDGs) were launched in the year 2000. Of the eight goals, two were concerned with education. Goal 2 pertained to achieving universal primary education - its target to: 'Ensure that, by 2015, children everywhere, boys and girls alike, would be able to complete a full course of primary schooling'. Goal 4, on the other hand, sought the elimination of gender disparities in primary and secondary education - preferably by 2005, but at all levels of education no later than 2015. In 2008, the MDGs Africa Steering Group Report (June 2008) noted that several African countries were on track to achieve the goal by 2015. The report noted, however, the need to improve curricula, strengthen the management of education systems, provide better teaching materials and increase expenditure for the training and management of teachers. The universal target for 2015 turned out to have been rather optimistic because, in January 2014, the Education for All (EFA) Global Monitoring Report noted that the world was set to miss the goal of full primary schooling for children, both boys and girls, everywhere by 2015. This paper focuses on MDG Goal two and examines the reasons why not all boys and girls could complete a full course of primary education by 2015. The conceptualisation of literacy practices and events was used as the motif of analysis of data from a study that employed a variety of research methods. Questionnaire surveys, ethnographic observations, focus group discussions and interviews were used to document some of the reasons why Sub-Saharan African (SSA) countries and Tanzania in particular were also missing the MDGs.

This study focused on literacy practices, events and perceptions that characterise the homes, schools and communities to promote early literacy development at home and school in rural, low-resourced communities. The notion of literacy practices refers to the way of conceptualising the link between the activities of reading and 
writing and the social structures in which they are embedded and which they help shape. These are 'the general cultural ways of utilising written language which people draw upon in their lives ... what people do with literacy' (Burton, Hamilton and Ivanic 2000,7). On the other hand, literacy events are activities where literacy has a role; usually in the form of a written text, or with texts being central to the activity. Events are thus observable episodes which arise from practices and are shaped by them (Barton, Hamilton and Ivanic 2000). Meanwhile, literacy perceptions were the views that participants held about the role and place of activities that centred on reading and writing in their communities. This paper identifies the reason for the challenges of low literacy rates - widely recognised to be greatest in Sub-Saharan Africa (SSA) - as emanating from the state of contemporary literacy environments and infrastructure. UNESCO (2008) says that the challenges of low literacy rates are widely recognised to be greatest in Sub-Saharan Africa and further asserts that the region has the highest proportion of out-of-school children, the greatest gender disparities, the highest ratio of pupils to teachers and the lowest primary completion rates. The paper sets out to answer the question why literacy development appears to be lagging behind in Sub-Saharan Africa, leading to unsustainable access to schooling for children from low-resourced communities?

There is no contention that a strong correlation exists between poverty and illiteracy - indeed, wherever literacy rates are lower, poverty rates are invariably higher and vice versa. In sub-Saharan Africa, most people survive on incomes of less than a dollar a day and cannot afford to send their children to school. In the study area of Lindi Rural District, 79.8\% of parents were living on about Tsh50, 000 per month, equivalent to about two dollars a day, with the majority (80.8\%) indicating their highest level of education as primary school. It is little wonder that parents and teachers perceived literacy development positively but could not translate this to positive reinforcement of literacy practices in the homes and schools. For example, $89.7 \%$ of the teachers perceived that literacy could help one to gain more access to knowledge in everyday life and help one to become a critical thinker (85.5\%) while it could help children to pass from one standard to another (87\%). Although parents did not get involved in their children's learning at home or school (only 16 $\%$ indicated involvement in school committees), they still perceived that the early development of literacy could benefit from family involvement, including that of siblings (86.6\%), parents (88.5\%) and also from listening to stories by parents and other adults $(84.0 \%)$. This unfortunately, means that the majority of the people in these contexts cannot hope to escape the spectre of intergenerational poverty through the educational fortunes of their children. This again means that their educational and socio-economic status is passed on and replicated among their children and their future generations. Interviews with two mothers at school 5, one of the five schools named $1-5$ in the study, reflected this when they were asked about the status of their children (pseudonyms used): 
Mama Fatu: "I have four children, all girls, the eldest has completed school, that is class seven, and the others are classes five, four and one."

Mama Zuura: I have four children, the first being 18 years, completed primary school but did not pass the primary level exams. The second is 13 years and in class five; the third is eight years and in class one and the fourth is three and half years and not yet in pre-school.

This is a disconcerting state of affairs with regards to efforts to reduce extreme poverty and hunger since a low literacy rate is a major barrier to personal improvement that prevents the poorest people from lifting themselves out of the poverty trap (UNESCO 2008).

\section{OBJECTIVES AND FOCUS OF STUDY}

The objectives and focus of this study were to examine the literacy practices and events found in the communities - that is, the general cultural ways in which communities utilised written language and how their contexts reinforced these. The study set out to establish the factors embedded within the school, family or community structures that promoted the activities of reading and writing for the three to eight-year-olds in rural, low-resourced communities. These were examined together with other sociocultural activities where literacy played a role - where written texts (and talk around these texts), were central to the home or family activities.

\section{METHODOLOGY}

This paper is based mainly on findings from the case studies component of a Literacy Development study based on a sequential mixed methods design. The design was preferred for its ability to offer balanced perspectives based on the triangulation of methods and results from the quantitative statistical and the qualitative interpretive validity and reliability respectively. While the survey data offered generalisability, the ethnographic case studies produced thick data from focused multiple methods for multilevel analysis. The questionnaire survey involved all 101 schools in the Lindi Rural District of Southern Tanzania where 15 were used in the pilot, 86 in the main survey roll out and five (from the same 101) for the small scale vertical case-studies. The ultimate aim was to establish early literacy development indices that could be used to determine the most effective pedagogical choices for teachers and home support strategies for parents. The case studies explored the extent to which literacy practices, events and perceptions were tenable in the contexts of the homes, schools and communities and how they impacted on each other and on educational outcomes. The analysis was therefore based on the suitability of these communities and schools to nurture literacy practices and events - establishing the general cultural ways communities and schools utilised written language and drew upon it in their lives. The study was interested in understanding this from a micro-level context (Vavrus 
and Bartlett 2006) and, hence, focus was on the five primary schools selected on the basis of different traits in performance records as well as resource bases and types of curriculum. Two sets of schools were selected for good and poor performance and for having and not having adequate resources respectively. A special school, catering to visually impaired children, was purposively selected for find whether it offered different challenges regarding literacy development for the visually impaired.

Data collection methods included focus group discussions (FGD) and one-onone interviews with parents and teachers, as well as classroom observations. Broad observations of the school environments were made to establish the ecology of each school and classroom, including level of availability of appropriate resources. Data recording was done using a LiveScribe pen (http/www.livescribepen.com) and video and digital sound recording. Field notes were used as well since researchers wanted to ensure that they kept further back-up information deemed important at different points of the field work for quick reference and verification. Ethical concerns were addressed by ensuring that a research clearance permit was obtained from the relevant Ministry of Education and Vocational Training and that all participants were made aware of the purpose of the study before their consent was sought. Participants consented first before they signed the relevant consent forms after understanding their rights and privileges. Either the parents or the school teachers signed assent forms on behalf of minor children.

Five primary schools and 10 homes were used for observations of lessons, classrooms as well as environments, interviews, focus group discussions and document analysis. Forty- four teachers from pre- and lower primary participated in FGDs and interviews and 24 and 13 parents participated in FGDs and interviews respectively, as indicated in the table below.

Table 1: Interview and FGD in homes and schools

\begin{tabular}{|l|l|l|l|l|}
\hline School & $\begin{array}{l}\text { Homes visited } \\
\text { per school }\end{array}$ & \multicolumn{2}{|l|}{ Focus Group Discussions } & Interviews with \\
\cline { 3 - 5 } & Parents \\
\hline S1 & 2 & $\begin{array}{l}2 \text { groups of twelve } \\
\text { parents each }\end{array}$ & $8(6 \mathrm{M} ; 2 \mathrm{~F})$ & 4 \\
\hline S2 & 2 & - & $5(4 \mathrm{M} ; 1 \mathrm{~F})$ & 3 \\
\hline S3 & 2 & - & 4 teachers & 2 \\
\hline S4 & 2 & - & $21(14 \mathrm{M} ; 7 \mathrm{~F})$ & 2 \\
\hline S5 & 2 & - & $5(3 \mathrm{M} ; 2 \mathrm{~F})$ & 2 \\
\hline TOTAL & $\mathbf{1 0}$ & $\mathbf{2 4}$ & 44 & 13 \\
\hline
\end{tabular}




\section{FINDINGS}

\section{School ecology and infrastructure}

\subsection{The environs}

Although, the five schools were selected on the basis of difference in performance, resources and types of curriculum (as indicated in the methodology section), they did however have many similarities. Most of them possessed large swathes of land used for different purposes including cashew nut plantations, crop growing and school playgrounds. In the majority of cases, teachers had no accommodation at the school premises but rented at near-by service centres and lived as part of the communities, sharing resources such as water from local sources with the local population and buying from the same markets and vendors in the communities. This sharing of communal resources brought teachers close to the parents, a factor that could be taken advantage of during school and home interactions. From these interactions, teachers and parents would become aware of, and able to support, the literacy practices and events at home and in the schools.

\subsection{The classrooms}

The area of study in Southern Tanzania is hot all year round and classrooms need to be kept cool and well aerated. This explains why the majority of classrooms have doors and windows that do not close because they have no latches or locks. The classrooms were therefore open to wind and dust - the reason for the very dirty and dusty wall and floor conditions encountered. Under such conditions, the link between literacy practices (reading and writing activities) and school structures remained very strained and the same was found to be true of activities where literacy played a central role with written texts and talk around texts (literacy events). Nurturing literacy practices and events required ecological conditions that could sustain the creation of appropriate talk, written texts, their display and reinforcement. The schools, in general, looked old and unkempt, although the majority were built after independence in 1962. In some extreme cases teaching was going on in partially collapsed buildings, exposing both teacher and students to great danger. Again, these were not conditions suitable for reading and writing activities since teachers could not use the chalk boards or store any teaching materials in these classroom structures. In the five case study schools, enrolment and resources varied considerably, usually with stark contrasts. In some classrooms, half the pupils sat on the desks while the other half sat on the floor, while in other classrooms, pupils were crowded together in ways that could not enhance effective development of written texts. 


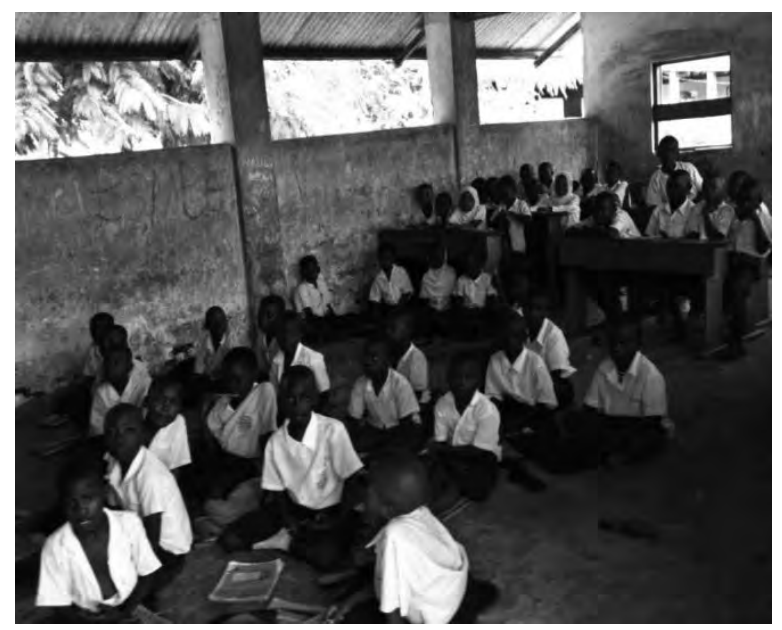

Figure 1: A classroom in which half the children had to sit on the floor and the other half on benches

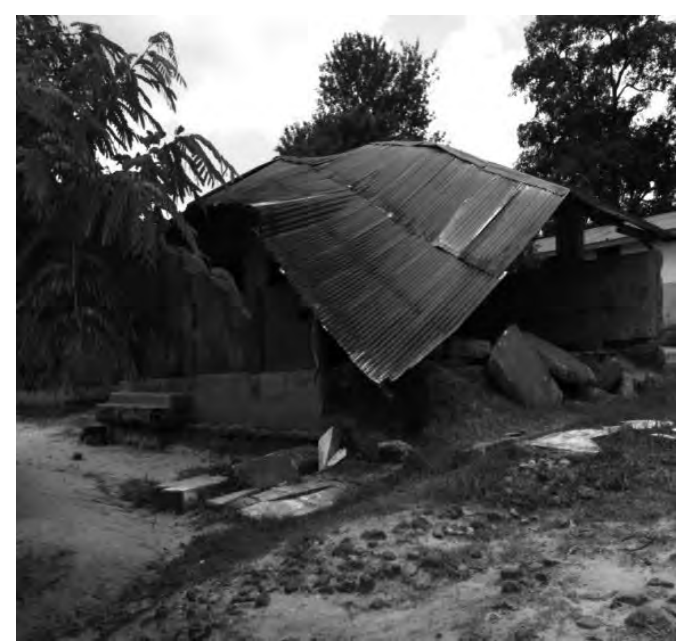

Figure 2: A collapsed school building. Fortunately nobody was hurt in this incident (illustration of the level of neglect) 


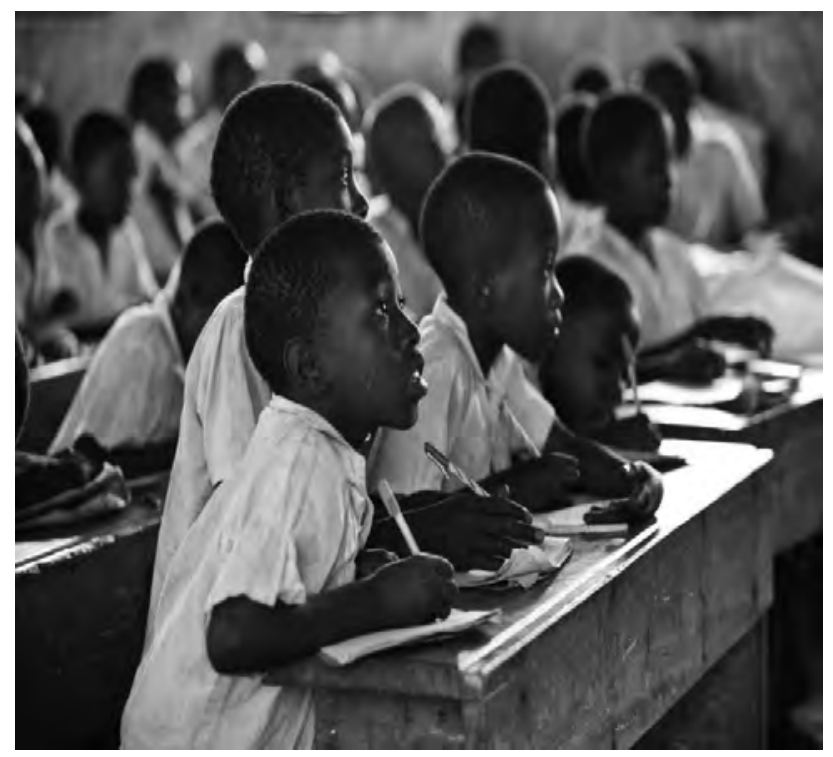

Figure 3: Writing in exercise books - children with inadequate space due to crowding

Under these conditions, facilities and materials were not always ideal - being inadequate in some and completely missing in others, all leaving the children unable to consistently conceptualise the link between the activities of reading and writing and the school structures. Throughout, literacy texts such charts were not a common feature of the classroom walls and talk around texts was usually absent, factors that severely limited literacy development opportunities for children in these contexts. The extent of barriers to literacy development was mainly due to children missing out on constructive literacy practices - not having undertaken constructive written work in their exercise books up to the end of year and missing out on opportunities to develop texts themselves. The classrooms for the visually impaired had different attributes from the other ordinary classrooms. It was noted that the school with the special visually impaired section was better resourced than other schools although they also needed more. The head teacher revealed that it was a beneficiary of the Roman Catholic Mission of which it was part and, as a result had access to adequate resources although they needed more. Visually impaired teachers taught this class and each child had adequate resources to use - each, their own special typewriter 
and special braille paper and a designated place to store them. This was the one classroom observed with suitable conditions for reading and writing activities and children and teachers appeared to be genuinely engaged with literacy practices. The head teacher said that the visually impaired teachers were among the most dedicated of his staff.

\subsection{The teachers}

While teachers must be the main protagonists in the school domain as regards supporting both practices and events, in these schools they appeared to be very lukewarm about their work, almost as if they were disinterested participants carrying out tasks they were not enthusiastic about. The only exceptions were the visually impaired teachers, as indicated in the section on classrooms. At case study school 5, the head teacher appeared to suggest that the research team was interfering, despite the visit having been arranged in advance by the Education Academic Officer (EAO) who was present. The head teacher grudgingly organised for the classroom observations and eventually taught one of the classes himself. The EAO said it was good that he (EAO) was always in our company; otherwise some of these teachers and heads could just refuse to cooperate. Except for a few cases, they often did not prepare learning resources for their lessons, did not have charts on the walls, did not mark pupils' exercise books constructively and had a carefree approach to their work. With the exception of the visually impaired teachers - who engaged their children effectively around reading and writing activities - the teachers were the weak link in the literacy practices and events discourse. They did not create opportunities and materials that could link the activities of reading and writing to the school structures and did not support children to develop consistent literacy perspectives. When learning resources were available, they did not use them effectively. Their general ways of utilising the written language was not reassuring. This was observed in a 'well prepared' English lesson ironically under the heading: Expressing Location referring to the teaching of prepositions 'on, in and under' at school 5 . The learning teaching media that had been prepared were a ball, bucket and table. The teacher taught the prepositions as stand-alone structures with no reference to the prepositional phrase context. The teacher therefore, adopted the drilling method; repeatedly asking children to chorus the preposition items - on, in, under! "The ball is on; the ball is in; and the ball is under" with no reference to the objects of the preposition to which the ball related - "on the table"; "in the bucket"; "under the table" for the complete semantic of the structures in context.

The teacher did not have the confidence to make the full phrases - 'in the bucket, under the table, etc'; hence failing to take full advantage of the teaching media available. 


\section{Teaching prepositions}

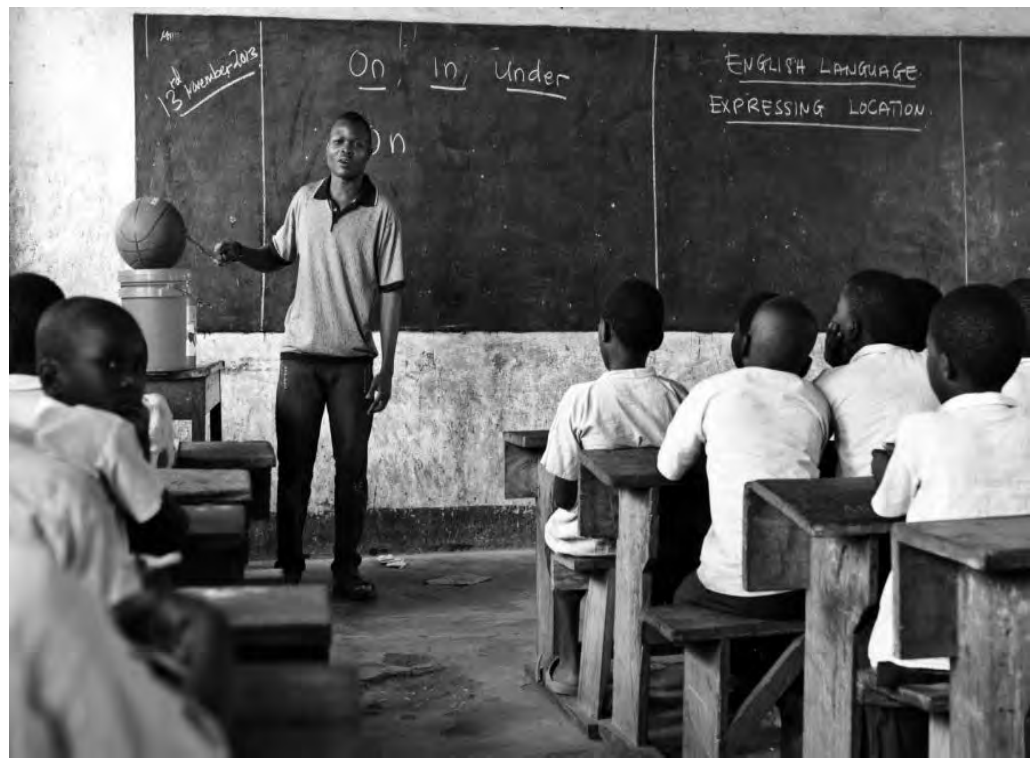

Figure 4: Literacy practices challenged

Even with available teaching materials, teaching remained patchy with no full sentences on the board or full phrases based on prepositions as teaching points.

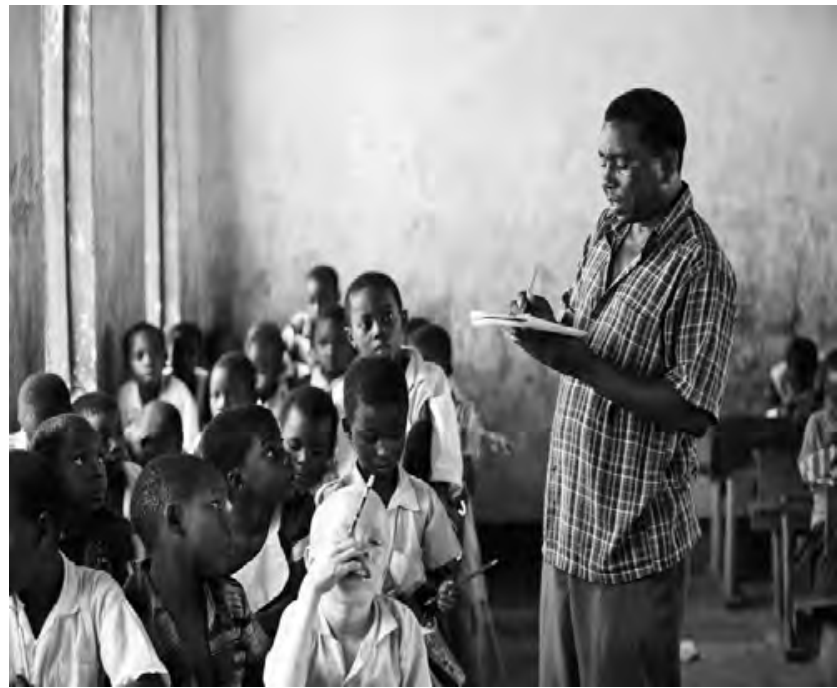

Figure 5: Challenging teaching and learning conditions for literacy development 
In school 1 FGDs teachers reported that parents did not want the school to have effective teaching that could make children pass their Standard 7 examinations since they wanted to avoid the bother of paying secondary school fees. To an extent, it could be said that the school situation resembled a façade with no genuine players and, therefore, with no educational literacy outcomes as a priority. It was regrettable that schools did not possess adequate infrastructure; teachers did not have the enthusiasm or teacher content knowledge to utilise the written language and create texts and talk around texts effectively. The links between reading and writing activities and the curriculum structures in which they could have been embedded and which they could have helped to shape were weak. The schools simply did not possess the conditions or qualities to support enduring literacy practices for the children in these low-resourced communities.

\section{IMPLICATIONS FOR PEDAGOGY}

The conditions and activities in the classrooms did not usually draw upon literacy practices and events and therefore did not represent the best way for children to access sustainable schooling. According to Fataar $(2011,64)$, an expanded definition of education access includes concerns for attendance as well as enrolment, progression at the appropriate age, achievement of learning goals, equitable access to opportunities to learn and the availability of an adequate learning environment. The classroom conditions uncovered in the course of this study - with children sitting on the floor or with few learning resources or unhelpful learning experiences - appeared to reinforce the fact that, while children were enrolled (access), their classroom activities did not draw upon the utilisation of effective literacy practices. In these classrooms, writing meaningfully in exercise books and talking about written work was not the usual way of utilising the written language and teachers and children did not, therefore, have the opportunity to talk around the texts being studied. The dirty floors and books inevitably meant that proper writing conditions and properly written texts were not available and therefore could not become central to the literacy activities in the class, effectively making the possibility of teacher and child talk around the texts impossible. The school and classroom conditions tended to impede effective development of literacy practices that teachers and children could draw upon and establish as the way their learning could be defined. For example, in case study school 5, during a focus group discussion (FGD) with all eight teachers, the head teacher blamed the district office (of the Ministry of Education) for the conditions the schools found themselves in, accusing the district office of not helping the situation. He alleged that the district office offered no help; rarely visited the schools to see conditions for themselves; did not increase capitation grants; left the small grants being disbursed to very late in the year (if they were disbursed at all); and did not seem to mind that children went through 
unprofitable learning experiences. The Education Academic Officer from the district office was part of the research team as collaborator and was present during the FGD. Later he expressed disappointment at the head teacher's comments, stressing that school heads were expected to run the schools like experienced professionals with innovativeness and integrity. Acknowledging the poor situation, he however still insisted that school headship was not about blaming government or district office for problems, but making innovative decisions. Regrettably, while the blame game raged, the infrastructure in place did not enable effective learning to take place as both the school's and children's opportunities to develop meaningful literacy practices were severely diminished. What the head teacher was saying was that the current school conditions prevented meaningful literacy practices from taking root and that daily school activities could not create viable literacy events since they were devoid of written texts and discussion of texts by teachers and pupils. Difficulties faced by schools to establish enduring literacy practices and to engage children in literacy events left the schools less attractive and made teachers less enthusiastic about their pedagogical practices, hence creating a literacy development deficit cycle.

It was not surprising when, in a plenary meeting during the main survey rollout, one mother asked the research team if they could provide an explanation for the behaviour of her eleven-year-old son (Class 4) regarding absenteeism. The boy did not want to go to school, she said, instead calling his friends to come and play football in the open space outside their compound. Teachers had not complained or come to find out, yet the school was close to the home. This scenario was further evidence of lack of the viable literacy practices and events at school and the lack of parental involvement in children's school experiences. Boys did not find it worth their while learning in classrooms depleted of literacy materials, with no meaningful opportunities to develop written texts and talk around texts with teachers. The pedagogical practices based on teacher talk with no parental involvement made them to look for something more interesting such as playing outside the village compound. 


\section{CONDITIONS IN THE HOMES}

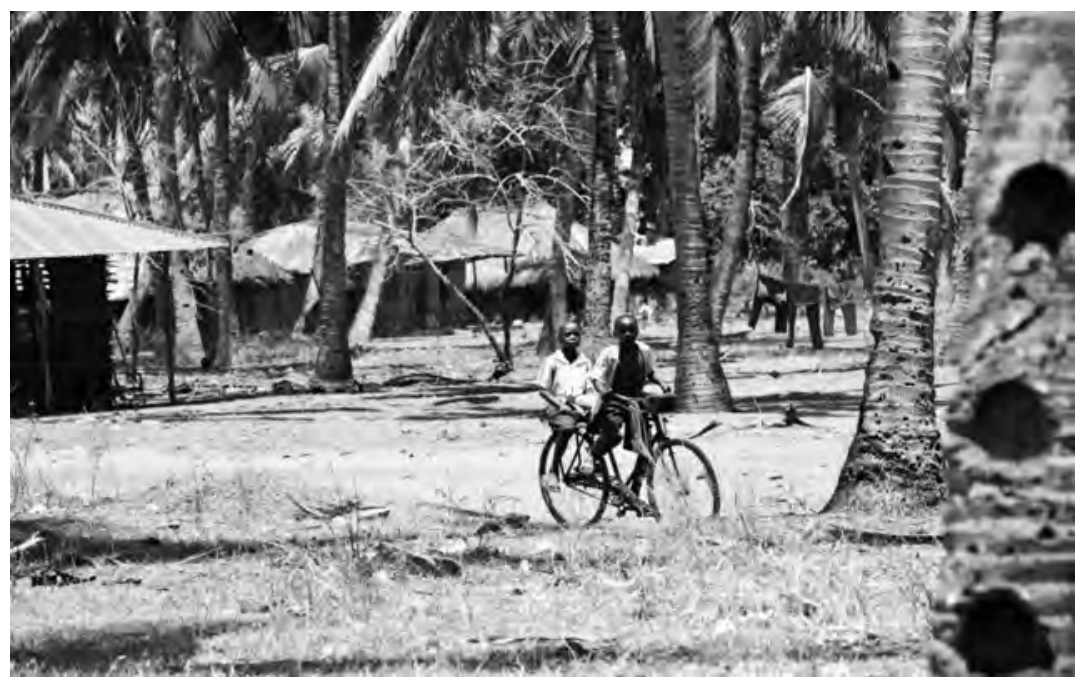

Figure 6: Clustered linear structure - these are not conditions where reading and writing can be central

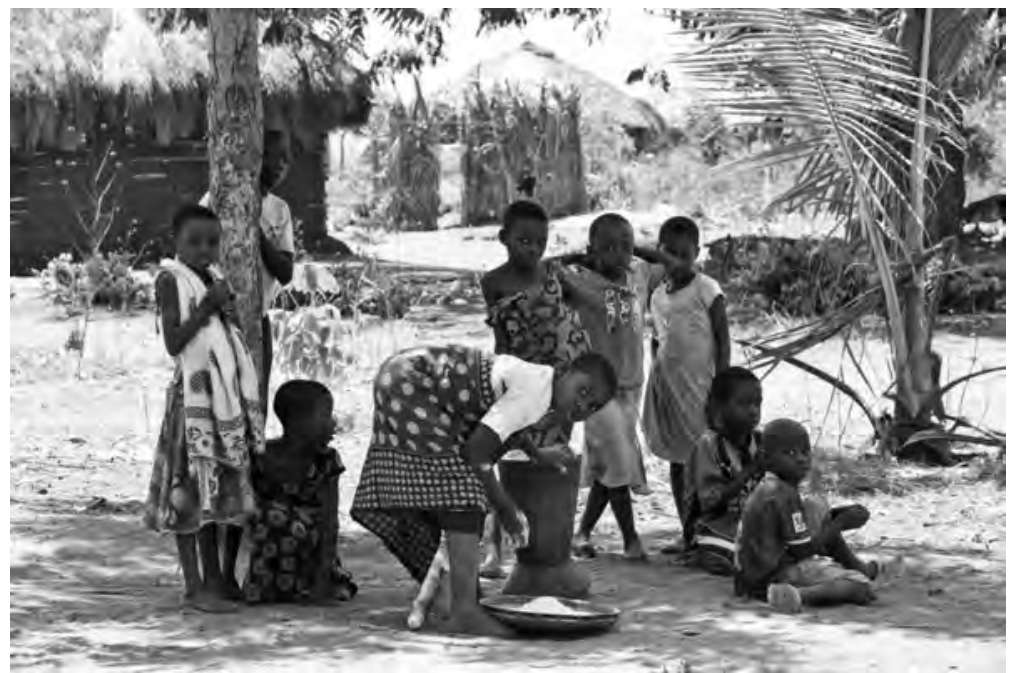

Figure 7: Despite few direct school literacy materials, homes were still full of vibrant contexts of socio-cultural knowledge that could be tapped into for school literacy 
Generally, homes in the study area occurred in cluster-type village settlements with families owning the land where their houses and huts were built. The houses comprised a variety of basic structures of pole and mud or mud walled with stone and reinforced with twigs and with roofs of coconut tree leaves or corrugated iron sheets or tin. Buildings always looked weather-beaten and in a state of disrepair. However, some homes had more permanent structures under iron sheet roofing with adequate facilities for family needs. The homes were furnished with basic but appropriate furniture items, including locally-made furniture - beds, chairs, tables and stools as well as other paraphernalia for household use. It is worth noting again that the locally-made furniture was usually of good quality and well suited for the lifestyles of the villagers. Gadgetry to be found in the houses included coconut flesh extracting devices (mbuzi), miniature pestles and mortars for spices, mixers and special charcoal stoves, as well as decorations and cultural and religious artefacts significant in the lives of the villagers. Although homes did not have outright resources for schooltype education, such as books and stationery items, the items they possessed were still adequate for education compatible with the families' cultural heritage. These resources were still versatile enough to become the basis of school education since utilisation and reinforcement of written language and talk around texts could have been developed around them if teachers, parents and communities knew how to exploit them (resources) for that purpose.

\subsection{Home and school interplay}

The villagers were peasants who extracted their livelihoods from the land and water as farmers and fishermen (the study took place in coastal and wetland areas). Millet, cassava and bananas were the main food crops while cashew nuts, coconuts and cassava (again) were small-scale cash crops. From the case studies, unemployment among young people and women and contextual socio-economic as well as political factors appeared to dominate villagers' lives. Populations still had strong beliefs in supernatural powers and some traditional practices outlawed by the United Nations, such as female genital mutilation. These conditions threatened the achievement of universal education as there appeared to be no room or opportunity in the home setting to allow parents and children to draw upon written texts or talk around texts. Parents did not have any habit of showing interest in what their children were doing, dismissing that as children's play that did not require the presence of adults. "There is no way we can play with children, maybe just watch them from a distance because they are just playing," said both the mother and father from family 2 of school 1. Children's play, as home and community resources, did not reinforce literacy practices and events and therefore did not link with schools activities. The fact that parents' highest level of education was standard 7 for most fathers, and often standard 5 or no education at all for many mothers, was an acute setback for the development 
of literacy practices and events in these communities. This was partly the reason why parents' expectations in respect of children's school education was minimal and motivation to promote children's education was very low - children are known to have been encouraged by parents to fail primary school exit examinations so as to avoid having to find the finances for secondary school fees. Stories from separate parents and teacher FGDs about the extent to which parents went to discourage children from achieving good educational outcomes were unusual, but corroborated by the education officer as embarrassing but true. Teachers were afraid of using effective pedagogies to enable learners to achieve good results because they would incur the wrath of their parents. These were not the conditions where communities believed in the utilisation of the written language as a way of reinforcing children's sustainable access to schooling. At case study school 1, teachers testified about their frustration regarding the parents' attitude and opposition to school goals. Children came to school tired and were likely to be dozing as early as the first lesson because they had spent long hours at night service centres that had electricity and entertained clients (including children) to music and video games until the morning hours. These were not conditions under which literacy practices could flourish as activities of reading and writing could not naturally embed themselves in the social structures of these environments as everyday activities were not centred on written texts and could not translate to literacy events. The traditional ways of communication as whereby parents tell children what to do and children obey instructions, was dominant and left no opportunity for parents to show interest in what children were doing or to talk about the children's activities. Those few parents who were aware that early literacy development could enable them to break the cycle of poverty expressed desperation about their poverty and inability to help their children complete primary school.

\section{HOME, SCHOOL, POVERTY AND LIFE PERCEPTIONS}

This section discusses the different reasons that militated against the utilisation of the written language as a cultural practice and why communities could not draw much from the practice. FGDs indicated that many families were in a gridlock of peasantry that prevented them from appropriating meaningful development or the advantages of literacy and school education in the main. As peasant farmers they were largely surviving on the margins of society where nobody appeared to be concerned about their marginalised socio-economic status. Many families had serious food insecurity issues since their farming yields hardly lasted until the next harvest (school 5) (Ngwaru, Mwingi and Oluga 2013). Sometimes boys dropped out of school early or simply joined their fathers in small-scale fishing and/or farming after Class 7, which appeared to be end of school for the majority of children. Girls were deliberately encouraged to drop out of school at about standard 5 or 6 (13-14 years) to go to the 
cities and towns to look for house-maid employment for three or four years and then come back to the village well-groomed for marriage (school 2). The intricate web of poverty, little education and helplessness left communities not trusting school education and therefore not embracing the utilisation of the written language or literacy texts. These were not conditions under which literacy development could hope to be prioritised or under which there could be any hope that the situation might change in the short or intermediate future. For example, in home 1 (H1) of school 2 (S2), none of the nine and 10-year old siblings in classes two and three respectively were able to write their own names. This situation did not alarm the parents who, in any event, did not seem to trust the usefulness of school education. Instead, the interview at $\mathrm{H} 1$ of $\mathrm{S} 1$ revealed that two girls of about the same age (9-10 years) were already very good at cleaning around the house, fetching water and washing their clothes and could both cook all the local dishes. The elder sister was available to explain how to prepare a whole local menu based on the staple food 'ugali' - derived from maize flour - and green vegetables.

In her words:

For ugali:

- Boil water, add flour, and then stir to required thickness.

And vegetables:

- Cut vegetables, tomatoes, onions, go and buy cooking oil, and add to the pan, fry add tomatoes.

To serve:

- Prepare water, serve vegetables in a bowl, wash hands and eat with grandmother and 'mama mdogo' (aunt - her mother's sister).

The child describes the process in real time, saying that after cutting tomatoes then you "go and buy cooking oil". There is a genuine understanding of the practice reflected by that originality. The grandmother said that she taught them domestic chores and always called them to stay around as she cooked. This ugali recipe was an eye opener and reinforced what we know about social cultural funds of knowledge (Moll 1990) that children could bring to school if parents and teachers were aware.

From interviews, observations and FGDs, the question of helping children with their school work or play was characterised by the majority of families not getting involved. Predominantly, the motivation for children to acquire school education was very low. Education did not appear important at all to the majority of the population in this part of Tanzania. A grandparent-led family in school 1 said that they went to school only when they were called, but that they had reservations talking to teachers about their children's abilities (because) 'if the children are able, they are able; and if they are not (able), they are not'. In school 2, one mother kept on saying that she had not gone to school herself and could not talk about what happens in the school, 'I did not go to school; it is my husband who knows about school and can tell you more'. The husband said that they had started to care about children's education 
only when their third child, now in class three, was beginning school since there had been much talk about pre-school even in the village at that time. On the other hand, in home 2 of school 3, there was a different feel with a boy doing the household chores as well, but going on playing /working on large toy cars he was trying to power by improvised electricity using copper wires, bulbs and batteries. According to the parents, the boy was just playing and not much had to be made of that. At the same time, many parents still talked about the importance of children's rites of passage including children's circumcision as part of initiation into adulthood ('jando na unyago').

Different from the negative attitudes against schooling gained from general interactions with villagers and teachers, there were isolated cases of parents advising children to take their education seriously. In the case of school 4, one parent said he advised his children to take their school seriously. 'Wasifanye masihara, wajipange juu ya masomo' (they should not joke/ play with their education but aim high). It is significant to point out that this school was part of the Mission school community and not the typical rural setting without other influences where parents and teachers clearly suggested that school education was not an interesting subject among villagers. Typically one of the mothers thought that she was not able to help children as she had not gone to school herself 'Kwangu, elimu ni mbali kidogo' - for me, education is a bit distant.

\section{THE CRUX OF LITERACY DEVELOPMENT CHALLENGES}

\subsection{A note on ethnographic practice}

Informed by and applying ethnographic procedures, researchers went into the communities hoping to understand the extent to which people's livelihoods were able to reinforce early literacy development on the basis of the analysis of social ecology and ambience for literacy practices and events development. The researchers' decisions were informed by the knowledge that participants were products of their environment - an environment that determined the times, places and ways in which they interacted. The team gained unique experiences and insights by looking at the possible links between community structures and the activities of reading, writing and creating texts.

\subsection{School education and social cultural practice}

The study unveiled different ways in which school education and socio-cultural ways of life were perceived. Here were people - mothers and fathers - who appeared to have been frustrated by generations of lack of cohesive societal and individual progress 
until they appeared to have no faith in social institutions such as schools, families or political governance. From that perspective, communities were not structured in ways that promoted the nurturing of literacy practices and literacy events were not integral to their social activity. On the whole, people in the study had given up on meaningful individual or community development and had become rather cynical about the possibility of breaking the poverty cycle, especially through the education of their children. With school education discounted as a possible escape route from poverty, literacy practices and events equally had no space to flourish. People in these communities had come to accept that there was not going to be a change to the current status quo where some people were important and where others, like themselves, were not. In the words of parent 1 in school 3: 'We are too poor for our plight to attract the attention of the politicians or anybody who might have the means to help us. They help people who are better than us'. Asked about what they thought could help their families break the cycle of haplessness caused by poverty, participating mothers said that it was up to God if He thought they were worthy His mercy. On whether they thought school education, or any education, could be the solution to their situation, they said that education had proved to be a pipe dream. This attitude was never going to promote the conceptualisation of the link between the activities of reading and writing and the community social structures. Due to a variety of social ills, literacy practices were not going to be given a chance at this stage. They said all the talk about school education or literacy development and the school demands that went with them were just some of the bothers they had become used to but they had not brought about any trace of difference. Their views were strengthened further by the fact that even the very few families they knew whose children had passed ' $\mathrm{O}$ ' Level had very little to show for it. In the process, families had come to see school education and community development projects as things that were meant only for other people and possibly for other regions of the country. It became clear why, in School 1, parents did not like their children to pass and did not like teachers who made an effort to help them pass.

\subsection{Women, families and literacy development}

One of the most critical findings had to do with the place of women in the family and society. Both women interviewed in school 5 had sad stories about their fragile positions in their families. For example, asked why she thought traditional knowledge and not school education was better to pass on to her daughters, mother 1 said so that if she were to leave the family when her children were still young, they could look after themselves. Asked why she would expect to leave, she said that it was because her husband was likely to be bringing a new wife and she could be leaving. In the second home in the same school, another mother was asked what she could do to help her daughters' schooling and she said there was not much point bothering 
with that since her husband could turn up any day and ask her to leave because he will be bringing in a new wife. Metaphorically this was a death knell for literacy development and the well-being of the entire society. Women need to be empowered urgently at individual family and community level because they, more than men, care more about children and the well-being of the family. It is women that can be trusted to help with school motivation and literacy development since they are often closest to children and family aspirations in such contexts. There was not much that could be done with regards to literacy development by women who had the lowest levels of education, confessed to knowing very little or nothing about school and did not feel they were permanent members of their own families. If all development efforts were genuine (and these were many in the study region), government, NGOs and donor development partners must begin by acknowledging that the empowerment of the woman's position in the family and community is an urgent development criterion for literacy development and social transformation.

This situation called for some genuine original consideration of the factors that could promote the utilisation of the written language as a way of stoking a change in the educational outcomes of the communities. Lack of the reinforcement of literacy practices and events appeared to be more a result of historical economic layering of society causing people to have negative attitudes about their prospects for progress and improvement. This had formed the hardest barrier against their ability to utilise and draw upon literacy practices and embrace school education as the possible gateway to individual and community development. For literacy development to flourish, it was clear that the real issues to be tackled were: parents' low educational achievement; lack of confidence in the value of school education; and intergenerational poverty.

\section{CONCLUSION AND RECOMMENDATIONS}

The target institutions - the schools and communities - had historical, economic and socio-cultural conditions that did not reinforce the conceptualisation of the link between activities of reading and writing and their (institutions') social structures. Again, their conditions did not create the appropriate ecology for activities where literacy had a role and where written texts and talk around texts could become central to their everyday activities. The communities were found to be preoccupied with different levels of challenges, including lack of development, intergenerational poverty and lack of employment opportunities for their youths. These factors appeared to have pushed the conceptualisation of literacy development from their list of priorities. Schools, on the other hand, were grappling with a range of systemic challenges, including the lack of resources and a lack of timely responses to school needs by responsible authorities, as well as with teachers, parents and children's lack of motivation to achieve. Many had, unfortunately, become cynical about school 
education because it had not delivered anybody they knew from the cycle of poverty. They had further lost trust in civil institutions again because they had proved over the years to be partisan and partial. It appeared that these were the challenges that needed to be the focus of all development agencies, including education stakeholders - government, NGOs, community leaders and teachers and parents associations. The starting point for immediate and medium term results could be community development projects through education to change world views, especially the conceptualisation of community sensitisation. Intensive community literacy programmes could address the symptoms by deliberately sensitising communities about the need to empower women, parents and teachers to change their world views about life in general, including gender equity, viability of governance, community development and the efficacy of education. Further sensitisation could target positive community engagement in the promotion of the aims of literacy development, the school in general, the curriculum and the education system. The development sectors will need a cohesive approach that would analyse the school and home parameters for the development of specific policies for innovative solutions. Solutions have to be sought regarding how low income children can grow up in environments where parental involvement in their education is neither minimal or absent and how low income parents can be made to see beyond their economic circumstances. Focus should be placed on real socio-economic development that can be initiated to move populations out of their cycle of poverty and disillusionment. It should be appreciated, however, that nothing can be done as a quick fix to redress the strong correlation between poverty, illiteracy and underdevelopment, but making a start will be the most positive way forward.

\section{REFERENCES}

Burton, D., M. Hamilton, and R. Ivanic. 2000. Situated Literacies Reading and Writing in Context. London: Routledge.

Farrell, J. P., and S. P. Heyneman. 1989. Textbooks in the developing world. Washington, DC: World Bank.

Fataar, A. 2011. Making Rights Realities - Education Access, Transitions and Equity in Education. Southern African Review of Education 17.

Fuller, B., and C. W. Snyder. 1991. Vocal teachers, silent pupils? Life in Botswana classrooms. Comparative Education Review 35 no. 2: 274-94.

Heyneman, S. P., and D. T. Jamison. 1980. Student learning in Uganda: Textbook availability and other factors. Comparative Education Review 24, no. 2: 206-20.

Heyneman, S. P., J. Farrell, and M. Sepulveda-Stuardo. 1981. Textbooks and achievements in developing countries: What we know. Journal of Curriculum Studies 13 no. 3: 227-46.

Moll, L., C. Velez-Ibanez, J. Greenberg, K. Whitmore, E. Saavedra, J. Dworin, and R. Andrade. 1990. Community knowledge and classroom practice: Combining resources for literacy 
instruction. Tucson, AZ: University of Arizona College of Education and Bureau of Applied Research in Anthropology.

Ngwaru, J. M., M. Mwingi, and M. Oluga. 2013. Parent teacher empowerment for sustainable schooling in Southern Tanzania: interim findings - Early Literacy Development baseline. Report presented at the Annual Research Institute, October 2013: Aga Khan University, Institute for Educational Development East Africa.

UNESCO 2008. Education for all: Global Monitoring Report. Paris: UNESCO.

UNESCO 2010. EFA Global Monitoring Report 2010: Reaching the marginalized. Paris: UNESCO.

Vavrus, F., and L. Bartlett. 2006. Comparative knowing: Making a case for the vertical case study. Current issues in Comparative Education 8(2), 95-103. 